\title{
POLITICAL ADVERTISING IN THE REPUBLIC OF KAZAKHSTAN: A COMPARATIVE ANALYSIS OF THE PRESIDENTIAL ELECTION CAMPAIGNS IN 2011 AND 2015 YEARS
}

\author{
Nassimov Murat \\ nasimov_m@mail.ru \\ Kyzylorda University Bolashak (Kyzylorda, Kazakhstan)
}

\author{
Насимов Мурат \\ nasimovm@mail.ru
}

Кызылординский университет «Болашак» (Қызылорда, Казахстан)

\begin{abstract}
Process of modernization and democratization of Kazakhstan society demands creation of advertising technologies that consequently promote the state's strategic and tactical tasks and increase the level of political culture among population thus contributing to strengthening of social stability. Political advertising is a specific form of communication influencing ideas of citizens concerning political subjects and objects. Society and political advertisement interconnection is considered in two different ways: on the one hand advertisement stimulates political development of a society; on the other hand, society develops advertisement technologies. Alongside with this, it is a way of political communication with voters, target influence to learn easily during election campaign. Political advertising shows the meaning of exact political force platform, invites to support candidates, to form opinions about political force in people's consciousness, to make psychological conditions to vote. The aim of the paper is complex research of evolution of political advertisement in Kazakhstan and its peculiarities in the period of Presidential elections 2011, 2015.

Keywords: candidates for President of Republic Kazakhstan, direct political advertisement, election campaign, indirect political advertisement, social networks.
\end{abstract}

\section{Introduction}

Any activity of advertising is directly linked with information, because advertising develops political culture in society and also contributes to disseminate political values. So, political advertising is direct impact advertising of election campaign and information influencing indirectly in a different way daily socio-political life of the community value. Majority establishes the concept of advertising with a direct special caption cards connection. However, currently, indirect political advertising is becoming the main source of information. Information, news, expert articles on the state policy and etc. on the mass media (newspaper, magazine, 
$\mathrm{TV}$, radio, Internet) make an indirect influence. In addition to that the role of social network in socio-political life is getting more important day by day. Nowadays political advertising takes the following activities in the community: "information - getting, editing and spreading information about important elements of political system work; education - giving full information about different level high school notion; socialize - cope with political norms, moral values and models; criticism and control - shape socio-political ideas and outlook" [1].

"Scientific Advertising" is a book written by Claude Hopkins in 1923 and is cited by many advertising and marketing personalities as a "must-read" book [2, p. 88]. The modern view of political advertizing in Kazakhstan is defined; firstly, by its involvement in globalizing information space of the world community, secondly the state sovereignty achievement of the republic. The political advertising is a set of information-communicative means, material and the intellectual values elaborated during cultural-historical development of society, favoring the formation of public consciousness and socialization of the individuality. It involves the culture of information transfer and the culture of its perception. The advertisement of Kazakhstan is shaped, structured, changes its properties and parameters, becomes complicated according to the changes in its carriers - the people, the people who unite and coordinate their interests with each other - economical, family-household, political and spiritual.

We think such articles about political campaign advertising abilities affection [3], and making them clear in our mind [4], a notion about concept [5], competition between an important political information and other kinds of advertisement [6], the impact of TV to residential [7] and experimental research on questions [8] cannot be ignored. There are some specific differences in political advertising calling for daily social life values [9] and modern political advertising in the Republic of Kazakhstan in the inter-electoral period [10]. However, the majority of given research work material covers Russian and Kazakh audience mostly.

\section{Methodology}

The bases of the research work are scientists' research works and information up a given issue. The methodological basis of the research is the general patterns of research, the principles, methods of the development, formation and development of the political advertising. In particular, the dialectical method of cognition enabled the issue of formation of political advertising in the Republic of Kazakhstan, features of the 2011 and 2015 Presidential Election. Political advertising can be identified systematically while using the structural-logical model. This methodology has the potential to consider the basic principles of political advertising. Obviously, this model is the synthesis of all scientific analyzes. The logic of these key results is reflected in the methods of structuring and systematization. Comparative analysis in science is a potential and versatile tool that enhances the capabilities of explaining and describing changes in processes that are aimed at achieving goals and objectives. In turn, the author compares the features of the 2011 and 2015 Presidential Election. Content analysis in scientific research is closely 
linked with quantitative and qualitative information, as well as expert interpretation. This approach analyzes the views expressed in scientific literature.

\section{Formation of Political Advertising in the Republic of Kazakhstan}

According to A.B. Amerkhanova and V.R. Meshkov, a special role in marketing in education is given to the state. It provides legal protection of subjects of marketing relations from monopolism, as well as from bad faith in business and advertising [11]. Since political advertising enhances competitiveness, enterprises should also think about it. According to domestic researchers in order to obtain an adequate attitude and customer loyalty, one should use methods of communication policy, which include advertising, communication and promotion of services [12]. In an article where Greek political advertising is considered in retrospect, the authors compare the periods pre-recession (2004-2009) with the period of the recession (2010-2015). The study showed that comparative advertising among major political parties increased during the recession [13]. In an article that examines the relationships between political advertisements, party brand personality, voter satisfaction and party loyalty, the paper aims to address this gap in the academic literature by determining the relationship between the multifaceted advertising-brand personality-satisfaction-loyalty constructs in political context. The results of the study showed that the attitude of voters towards political advertisements had a significant impact on their satisfaction and loyalty when the brand identity played an intermediary role in this [14].

Up to now, political advertising formation in the Republic of Kazakhstan is divided into four periods: The first period of political advertising formation (the political ads for the first time to emerge) - 1991-1995 years differs with carrying foreign experience, the first advertising, which distributes information message in mass media was reportedly used. The second period of political advertising formed in the 1995-1999 years. Framework legislation of political advertising was established ("On Constitution of the Republic of Kazakhstan", "Constitution Law on the Election" and "Law about Mass Media" were passed). The third period is 1999-2004 years. The law "On Advertising", the basis of advertising activity order was held. Past election campaigns directly influenced the development of advertising methods. The fourth period is from 2004 to the present day. Arranging the advertising space and the political and legal rule basis were on updated process [15, p. 111-112].

As the given concept was announced in 2008, the fifth period covers eleven years; we can say that political advertising development time is from 2009 to the present day. Political advertising started developing on this period, especially the development of indirect technology. We can notice the synthesis between political and social advertising in some cases on interelectoral period. Election campaigns in 2011, 2012, and 2015 influenced the development of political advertising; wide usage of the Internet, was proved social networks. The state started to make account of giving political information through social networks, assessing it and discussing the other opportunities. In our country, the process of cyber socializing was quickly formed, and civil journalism started developing. 


\section{Features of the 2011 Presidential Election}

The presidential election in 2011 was different. Political advertising development with the lapse of time and domestic political technology school movement in a forward direction of time were evident. At the end of 2010 the initiative group in Oskemen organized a meeting with 850 citizens for the purpose of prolonging presidential term of the first president of the Republic of Kazakhstan. In a result in 2011 January 31 Constitutional Council legitimated considering to prolong the authority of Heads of State over the republic referendum changes and additions, because the law does not coincide to the constitution. That's why the leader of the nation N.A. Nazarbayev made a decision, by offering a way that connects country, to provide presidential elections ahead of time.

This year 22 electoral candidates were offered; three from political parties, one from the public association and 18 citizens proposed themselves. Comparing the election in 2005, four people gave extra offers. Zh.A. Ahmetbekov from the Communist People's Party of Kazakhstan, "Nature" Ecological Union leader M.H. Eleusizov offered himself, from Kazakhstan Patriot Party G.E. Kasymov and from "Nur Otan" People's Democratic Party, incumbent president N.A. Nazarbayev took part in this election.

As usual, the Central election committee of the Republic of Kazakhstan led several agitation works inviting residents to political campaign and organizing propaganda with the slogan "a country willing to choose!" According to informal sources an institution organizing election procedure prepared in general 23 commercials. Singer stars were not indifferent for the important political events of the country and shared action with the slogan "Vote for Kazakhstan" with young people. Cellular communication companies of Kazakhstan invited electorates to vote, saying "Make your choice!".

Although the candidates' leadership battle was not particularly high in the selective campaign, there were differences in the political advertising technologies. There were a lot of similarities in the candidates' program providing the people about country's development. Here, the usage of profitable advertising technology is considered to be topical for the destruction of the primary.

There was plenty of availability for candidates to campaign-advocacy the electoral struggle. In mass media not only direct, but also indirect political advertising was widely applied. The candidates used all the technology developed at the present-day era of the information age.

On the head menu of Communist People's Party of Kazakhstan site plenty of information was given about the candidate Zh.A. Ahmetbekov's election campaign with the political slogan "Right of work, power of people, justice". The candidate paid attention to, first, socio-economic importance of the country, lack of housing and communal activities price in his platform.

He raised three public initiatives in a new social circle direction. The first initiative is based on applying methods by identifying people under the life-being of the lowest activities according to multiply civilized country standards through the introduction 
of the goods and keeps service the lowest consumer budget structure. The second initiative considered to give the state guarantee to high academic graduates in getting work for the first time. The third initiative is to reduce the public living condition tariffs and price.

New ideas have been seen in political advertising. The candidate used a slogan, who several times gave a karate lesson, at the second lesson: "Righteous struggle net winning! Return competition and fight to politics!" He had a lot of slogans, but it seems a slogan "Vote for them! Zhambyl Ahmetbekov" was the best. We noticed this candidate used the media, the multiple impact of electorate opportunity. It is clear wide usage of social networks service "Moy Mir@mail.ru", worldwide information networks "Facebook" and "Twitter", website "www. knpk. kz" drove a great achievement [16]. $\mathrm{Zh}$. Ahmetbekov's elective headquarters created a community center "To support a reliable election", the main purpose of this organization is to take into account the right of citizens during the election and to support them. The communists updated state ideology and the idea of forming political and economic reforms differently stayed on the electorate consciousness.

President of the country imposes various duties; the "Nature" Ecological Union leader M.H. Eleusizov indicated ecology issue features of our country intensively compared with the election campaign six years earlier. At that time ecologist candidate's slogan was "Leader of a new era"; at this election his slogans are almost the same "The future is with us" and "With us to the future". His political platform was about advocating democratic institutes, intensifying friendship and cooperation between people, local authorities' managing themselves, the court's independence, the word freedom and the freedom of the press, fight against corruption, developing agriculture, mother and children problems. On campaign his union invited people to participate in traditional tree planting on Nauryz holiday. Showing that ecology and economy is the same concept he shared his opinion about economic troubles. The candidate conducted a model meeting with the students of D. Serikbaev East Kazakhstan State Technical University, L.N. Gumilyov Eurasian National University and Al-Farabi Kazakh National University professors and teachers of the faculty of biology in order to strengthen communication with the youth. Overall M.H. Eleusizov's participation on this political campaign indicated again that treating ecology is a time requirement.

It seems that the leader of the Patriots Party G.E Kasymov changed his image on this election. The candidate was purified from characters like throwing vase and glass breaking on TV shows. In 1999 political campaign he got most electorates attention by saying "I will regulate discipline by a strict hand", "On the way to truth and responsibility" was as an appeal $[15,124]$. This time G. Kasymov offered current potential development strategy of people in his platform with these slogans "My way is my people's way", "We are together with people". He paid attention to all official parties entering the parliament on the way of updating political system. It is said that the President will establish stable advisory body with the representatives of political parties. He stated devolving to the Parliament downgraded seven percentage barrier passage of the Act, the three called the size of the effective interest. He drew the 
attention of the legislator lines combining the need to introduce changes in the areas of the State power and paid much attention to the ways of organizing it. The idea of making multiple changes in executive authority was found in his political platform. The leader of Patriotic Party, who considers the slogan "Kazakhstan is for Kazakhstani people" as his main purpose, declared that he will observe a public holiday called "Mother tongue" and the idea "Democratic Kazakhstan is for all Kazakhstani people" was actual for him [17].

Incumbent President N.A. Nazarbayev proposed election program "Building the Future Together". The head of state, as usual, did not take part in the work of propaganda at the election campaign. It was the confident action of the Head of State, who conquered the twentieth anniversary plateau of the independence.

The growth of well-being of the people, progress in knowledge and medicine, advanced economy in Eurasian space, and the global know-called associative experience were as "Our achievements" in his elective platform. High level living condition, full growth, health, life comfortable state, economy growth, society peace and quiet, and life safety has been identified the precise plan for preceding years.

In 2011 the name of the President's Message, "We vote for the Head of State!", "Go ahead with the President!" used as the slogan on agitation-propaganda and memorized on the minds of the people. "Testimonials" technology joined the supporting citizens. In aforesaid kind of advertising familiar well-known citizens express their respect, choice and support for a certain candidate. Through expressing, a look they assert confidence supporting candidate's political credo. Along with this they can show their elective campaign activities on TV. In last election campaign political advertisement technology called "celebrities" was widely used only by propagandist group of the head of state. The world-famous personalities, actors, singers and athletes were involved in advertisements with the above technologies. "Kazakhstan-2020" national democratic forces coalition established by "Nur Otan" Party initiative took a lot of effort including political party leaders, community activists, and members of nongovernmental organizations in 2011 election.

"Azat" Nationwide Social Democratic Party and Communist People's Party of Kazakhstan did not participate on this early election, and it is known that some of them published boycott. Opposition press, which advocated actions of aforesaid parties at the previous campaign, published fuss moment of this election. For example, $\mathrm{Zh}$. Ahmetbekov's interview "Boycott is an escape from fight..." [18] with 88800 units was published in a weekly newspaper "Svoboda slova" before elective campaign.

\section{Features of the 2015 Presidential Election}

On 14 February 2015, the Council of Kazakhstan People's Assembly unanimously voted on the initiative to move presidential elections forward from 2016 to 2015.

KPA members' address to country residents: "We have to give new credentials of nation-wide belief just to give the right to President Nursultan Nazarbayev get country successfully in time of globalization," "increasing the credentials to the head of state 
$\mathrm{N}$. Nazarbayev in a time of a new and difficult period of the world balance, strategic directions and updates must be continued on the way of our country's joining the world's 30 most competitive economies". Along with this, they talked about that both presidential and parliamentary elections will be held in the same year and it needs to be provided in different years [19].

Communist People's Party of Kazakhstan and Democratic Party "Ak zhol" representatives in Mazhilis, the first who supported the Assembly initiative with Nur Otan Party. The secretary of Communist People's Party of Kazakhstan, A. Konyrov announced that they would offer a candidate.

According to legal procedures, the given issue was discussed by both parliamentary chambers of the country and public opinion. According to Constitutional Council decision on 25 February 2015 N. Nazarbayev signed a decree scheduling the early presidential elections for 26 April.

Presidential election campaign in 2015 involved 27 candidates, including political parties offered 2 candidates and 25 independent candidates. However, only three participants met requirements of political campaign: Abelgazi Kusainov is an independent candidate, Nursultan Nazarbayev is from Nur Otan Party and Turgun Syzdykov is offered by Communist People's Party of Kazakhstan.

The importance was mostly paid to young people during this election campaign. Different youth actions and competitions were organized. Especially, competition on topic "Your voice is your future" was organized on the Internet to increase voters' activity and to form citizens' deep legal consciousness in a society. Equal opportunities were given to all candidates to agitate on Republican and regional mass media.

According to Central election commission of the Republic of Kazakhstan 23105 materials about election were published in Republican and local media between 26 March and 24 April 2015. Candidates, for the President of the Republic of Kazakhstan, pre-election address was found in 13,379 materials, including the 4964 publication of the Republic, 8433 local mass media due. A. Kusainov published 4876 election materials, N. Nazarbayev published 5377 election materials and T. Syzdykov published 4905 election materials. All candidates used state guarantee TV fifteen minutes, radio ten minutes talking and two publications on press.

Central election commission controlled permanently all the materials published in media during election campaign. During the monitoring 53 republican publication, 16 republican TV channels, 179 regional publications, 29 regional TV channels, 7 news agencies and 117 famous socio-political Internet resources' materials were discussed. In social networks over 250 sites of over 200 associations and public opinion leaders were estimated. As the election campaign started 10,990 materials about election were published in republican and regional media. 1473 stories in republican channels (21\%), 731 newspapers articles (10\%) and on the Internet resources 4850 publications (69 $\%)$ were published. In regional media 3936 materials were published about election, including 1582 stories on TV (40\%), in publications 1637 articles (42\%) and 717 online resource materials (18\%) [20, p. 41-42]. If we noticed the number of Internet resource materials are increased. In the Republic of Kazakhstan there was not online 
activity up to this time. During campaign headquarters of the candidates for the president placed information-propaganda materials on special boards in all parts of our country. All the candidates used traditional pre-election advertising on publications and on TV channels. N. Nazarbayev's headquarter could actively use online and social networks opportunities. Communist People's Party of Kazakhstan restrained using press reports on their own site.

A. Kusainov, in his pre-election program "Ecological qualification and industrial safety is our main goal", paid main attention to ecology and industrial safety issue. On the program it is said: "People should know laws of biosphere development and the cause of dust possibilities. We have to contribute not to spoil the laws of biosphere development in a society. ... My purpose is to maintain proper preservation and clearance of these regulations". Easily achieved special terms in candidate's pre-election program is appreciated as few documents. He stayed in the voters' consciousness with the slogan "We realize environmental rules". Incumbent president took part in election campaign with his pre-election program "Modern state to all: five institutional reforms". The program is divided into three parts: Introduction- "Kazakhstan Great Way"; taking place condition characterization - "Danger of era"; the main part - "Five institutional reforms".

Nursultan Nazarbayev, as usual, did not participate in agitation-propaganda campaign at this election. The Head of State headquarter started propaganda work to keep stability in our country and to believe in the leader of our nation. It should be said that five political parties attended the headquarter work. In the current campaign the electoral party used the slogan "To new achievements with the Head of State!"

T. Syzdykov's election platform consists of several parts: Introduction - "To pay attention to Marxism heritage"; to argue main issues - "crisis of global system"; to prove main charges - "ideological heritage of Communist People's Party of Kazakhstan". In pre-election program the negative influence of western culture and values was criticized and it should be avoided. The candidate slogan is "Make your own choice!"

\section{Conclusion}

According to given above opinions political advertising implements these charges in order to play its role in campaign: to invite to vote on the basis of the social interests of society needs concept and forming a political culture of citizens; to publish and distribute public policy initiatives and values of the candidate to public; to inform and explain the news of election campaign; to influence by indirect information via the Internet resources and social networks.

Kazakhstan in the first years of its independence copied political advertising technologies of Western democratic values. In particular, found in electoral period, Russia and Ukraine specialists themselves, invited to election campaign, leaned in experience built upon foreign countries. Currently domestic political advertising quotation practiced feature and the need of state policy and specialists are basically 
based on our mentality. As it is shown in the 2011 and 2015 electoral campaigns indicated growth of the online technology influence can be noticed. It is a proof of the Internet significance in a domestic mediasphere. Along with this great importance is given to voters, which consisted of young people. Therefore, undoubtedly you need to involve this auditorium in taking an important decision at the next election. So, we do not have to forget that the political advertising will develop by updating the status.

\section{List of references}

1 Чугунов А.В. Политика и интернет: политическая коммуникация в условиях развития современных информационных технологий: Кандидатская диссертация. - СПбГУ, Россия, 2000. - 179 с.

2 Hopkins C. Scientific advertising. - New York: Merchant Books, 2014. - 126 p.

3 Ansolabehere S., Iyengar Sh. Going negative: how political advertisements shrink and polarize the electorate. - New York: The Free Press, 1996. - 256 p.

4 Daignault P., Soroka S., Thierry G. The perception of political advertising during an election campaign: A measure of cognitive and emotional effects // Canadian Journal of Communication, 38(2), 2013. P. 167-186.

5 Texas Ethics Commission. Political advertising. What you need to know, 2015. Retrieved from https://www.ethics.state.tx.us/guides/Gpolad.pdf (accessed 20 September 2017).

6 Coate S. Political competition with campaign contributions and informative advertising // Journal of European Economic Association, 2(5), 2004. P. 772-804.

7 Gentzkow M. Television and voter turnout // Quarterly Journal of Economics, 121, 2006. - P. 931-972.

8 Großer J., Arthur S. Neighborhood information exchange and voter participation: An experimental study // American Political Science Review, 100(2), 2006. - P. 235-248.

9 Nassimov M.O., Kaldybai K., Paridinova B.Zh. Features of political advertisement in the Republic of Kazakhstan // Middle East Journal of Scientific Research, 14(8), 2013. - P. 1129-1134.

10 Nassimov M.O. Modern political advertising in the Republic of Kazakhstan: interelectoral period // Reports of National Academy of Sciences of the Republic of Kazakhstan, 4(302), 2015. - P. 184-189.

11 Amerkhanova A.B., Meshkov V.R. University educational services marketing: features, opportunities, problems // Bulletin of National Academy of Sciences of the Republic of Kazakhstan, 6(382), 2019. - P. 208-213.

12 Kydyrova Zh.Sh., Satymbekova K.B., Kerimbek G.E. Urazbayeva G.Zh., Shadieva A.A. Increase of competitiveness of the enterprise (Example of the oil product market) // Reports of National Academy of Sciences of the Republic of Kazakhstan, 6(328), 2019. - P. 187-193.

13 Tsichla E., Hatzithomas L., Boutsouki C., Zotos K. Greek political advertising in retrospect: a longitudinal approach // Communication Research Reports, 36(5), 2019. - P. 404414.

14 Kaur H., Sohal S. Examining the relationships between political advertisements, party brand personality, voter satisfaction and party loyalty // Journal of Indian Business Research, 11(3), 2019. - P. 263-280.

15 Иватова Л.М., Насимова Г.Ө., Насимов М.Ө. Саяси жарнама: теория және тәжірибе. - Алматы, 2008. - 220 б. 
16 Президентские выборы - 2011. Электронный ресурс http://knpk.kz/wp/vy-boryprezidenta-2011/ (дата обращения: 01.02.2011).

17 Партия патриотов Казахстана - 2015. Электронный ресурс http:/ganikassymov.kz/ ru/page/partiya-patriotov-kazahstana (дата обращения: 25.05.2015).

18 Ахметбеков Ж.: Бойкот - это бегство от борьбы... // Свобода слова. - 2011. - 24 февраля.

19 KPA council suggests holding early presidential elections in Kazakhstan (2015). Retrieved from http://www.kazpravda.kz/en/rubric/society/kpa-council-suggests-holdingearly-presidential-elections-in-kazakhstan/ (accessed 16 February 2015).

20 Шибутов М., Нургалиева М., Булуктаев Ю., Абрамов В. Президентские выборы 2015: итоги и дальнейшие перспективы. - Астана: КИСИ при Президенте РК, 2015. - 94 c.

\section{Transliteration}

1 Chugunov A.V. Politika i internet: politicheskaja kommunikacija v uslovijah razvitija sovremennyh informacionnyh tehnologij [Politics and the Internet: Political Communication in the Development of Modern Technologies]: Candidate dissertation. - Petersburg State University, Russia, 2000. - 179 p.

2 Hopkins C. Scientific advertising. - New York: Merchant Books, 2014. - 126 p.

3 Ansolabehere S., Iyengar Sh. Going negative: how political advertisements shrink and polarize the electorate. - New York: The Free Press, 1996. - 256 p.

4 Daignault P., Soroka S., Thierry G. The perception of political advertising during an election campaign: A measure of cognitive and emotional effects // Canadian Journal of Communication, 38(2), 2013. - P. 167-186.

5 Texas Ethics Commission. Political advertising. What you need to know, 2015. Retrieved from https:/www.ethics.state.tx.us/guides/Gpolad.pdf (accessed 20 September 2017).

6 Coate S. Political competition with campaign contributions and informative advertising // Journal of European Economic Association, 2(5), 2004. - P. 772-804.

7 Gentzkow M. Television and voter turnout // Quarterly Journal of Economics, 121, 2006. - P. 931-972.

8 Großer J., Arthur S. Neighborhood information exchange and voter participation: An experimental study // American Political Science Review, 100(2), 2006. - P. 235-248.

9 Nassimov M.O., Kaldybai K., Paridinova B.Zh. Features of political advertisement in the Republic of Kazakhstan // Middle East Journal of Scientific Research, 14(8), 2013. - P. 1129-1134.

10 Nassimov M.O. Modern political advertising in the Republic of Kazakhstan: interelectoral period // Reports of National Academy of Sciences of the Republic of Kazakhstan, 4(302), 2015. - P. 184-189.

11 Amerkhanova A.B., Meshkov V.R. University educational services marketing: features, opportunities, problems // Bulletin of National Academy of Sciences of the Republic of Kazakhstan, 6(382), 2019. - P. 208-213.

12 Kydyrova Zh.Sh., Satymbekova K.B., Kerimbek G.E. Urazbayeva G.Zh., Shadieva A.A. Increase of competitiveness of the enterprise (Example of the oil product market) // Reports of National Academy of Sciences of the Republic of Kazakhstan, 6(328), 2019. - P. 187-193.

13 Tsichla E., Hatzithomas L., Boutsouki C., Zotos K. Greek political advertising in retrospect: a longitudinal approach // Communication Research Reports, 36(5), 2019. - P. 404-414. 
14 Kaur H., Sohal S. Examining the relationships between political advertisements, party brand personality, voter satisfaction and party loyalty // Journal of Indian Business Research, 11(3), 2019. - P. 263-280.

15 Ivatova L.M., Nassimova G.O., Nassimov M.O. Sajasi zharnama: teorija zhane tazhiribe [Political Advertizing: the Theory and Practice]. - Almaty, 2008. - 220 p.

16 Prezidentskie vybory - 2011 [Presidential elections - 2011]. Retrieved from http:// knpk.kz/wp/vy-bory-prezidenta-2011/ (accessed 1 February 2011).

17 Partija patriotov Kazahstana - 2015 [The Party of Patriots Kazakhstan - 2015]. Retrieved from http://ganikassymov.kz/ru/page/partiya-patriotov-kazahstana (accessed 25 May 2015).

18 Ahmetbekov Zh.: Bojkot - jeto begstvo ot bor'by... [Akhmetbekov Zh.A.: Boycott is a flight from fight...] // Svoboda slova [Freedom of Speech]. - 2011. - 24 February.

19 KPA council suggests holding early presidential elections in Kazakhstan (2015). Retrieved from http://www.kazpravda.kz/en/rubric/society/kpa-council-suggests-holdingearly-presidential-elections-in-kazakhstan/ (accessed 16 February 2015).

20 Shibutov M., Nurgalieva M., Buluktaev Yu., Abramov V. Prezidentskie vybory - 2015: itogi i dal'nejshie perspektivy [Presidential elections - 2015: results and further prospects]. - Astana: Kazakhstan Institute for Strategic Studies under the President of the Republic of Kazakhstan, 2015. - 94 p.

\section{Насимов М.}

Қазақстан Республикасындағы саяси жарнама: 2011 және 2015 жылдардағы президенттік сайлау науқандарына салыстырмалы талдау

Aңдаmna. Қазақстандық қоғамды жаңғырту және демократияландыру процесі барысында мемлекет стратегиялық және тактикалық міндеттерді алға жылжытатын, тұрғындарды саяси мәдениетін жоғарылататын, тұрақтылықты бекітетін жарнамалық технологияларды қажет етеді. Саяси жарнама - бұл саяси субъектілер мен объектілердің қатынастарына тәуелді азаматтардың ұстанымдарына ықпал жасайтын байланыстың ерекше түрі. Қоғам мен саяси жарнама арасындағы өзара байланыстарды екі жақты қарауға болады: жарнамалық қызмет қоғамның саяси дамуына себепші болады, екінші жағынан қоғам жарнама технологияларын дамытады. Сонымен қатар, бұл сайлау науқаны барысындағы саяси коммуникацияның электоратқа қысқа, өзіндік тез жаттауға құрылған адрестік ықпал жасаудың түрі. Саяси жарнама нақты саяси күштер саяси тұғырнамасының мәнін көрсетеді, сайлаушыларды қолдауға шақырады, саяси күштер туралы ойларды көпшілік санасында қалыптастырады, дауыс беруге қажетті психологиялық жағдай жасайды. Мақаланың мақсатына 2011 және 2015 жылдардағы президенттік сайлау науқандарындағы Қазақстандағы саяси жарнаманың дамуы мен оның ерекшеліктерін салыстырмалы талдау жатады.

Tүйін сөздер: Қазақстан Республикасы Президентігіне үміткер, тікелей саяси жарнама, сайлауалды науқан, жанама саяси жарнама, әлеуметтік желілер.

\section{Насимов М.}

Политическая реклама в Республике Казахстан: сравнительный анализ президентских избирательных кампаний в 2011 и 2015 годах

Аннотация. Процесс модернизации и демократизации казахстанского общества требует создания рекламных технологий, последовательно продвигающих стратегиче- 
ские и тактические задачи государства, повышающих уровень политической культуры населения, способствующих укреплению стабильности. Политическая реклама - это особая форма коммуникации, эффективная система влияния на установки граждан в отношении политических субъектов и объектов. Взаимосвязь общества и политической рекламы представляет собой двуединый процесс: с одной стороны, рекламная деятельность стимулирует политическое развитие общества, с другой стороны, общество развивает рекламные технологии. А также это - форма политической коммуникации в условиях выбора, адресное воздействие на электоральные группы в лаконичной, оригинальной, легко запоминающейся форме. Политическая реклама отражает суть политической платформы определенных политических сил, настраивает избирателей на их поддержку, формирует и внедряет в массовое сознание определенное представление о характере этих политических сил, создает желаемую психологическую установку на голосование. Целью статьи является сравнительный анализ эволюции политической рекламы в Казахстане и ее особенностей в период президентских выборов 2011 и 2015 годов.

Ключевые слова: кандидаты в президенты Республики Казахстан, прямая политическая реклама, предвыборная кампания, косвенная политическая реклама, социальные сети. 